Original Research Article

\title{
Comparison of therapeutic effects of monotherapy of chlorpromazine, risperidone and their combination in newly diagnosed schizophrenic patients
}

\author{
Tarun Vijaywargia*
}

Department of Pharmacology, Jhalawar Medical College and Associated group of Hospitals, Jhalawar, Rajasthan, India

Received: 01 June 2018 Accepted: 08 June 2018

*Correspondence to: Dr. Tarun Vijaywargia, Email: tarunvijaywari76@ yahoo.com

Copyright: (C) the author(s), publisher and licensee Medip Academy. This is an openaccess article distributed under the terms of the Creative Commons Attribution NonCommercial License, which permits unrestricted noncommercial use, distribution, and reproduction in any medium, provided the original work is properly cited.

\begin{abstract}
Background: This study evaluates and compares how negative and positive symptoms of schizophrenia were influenced with monotherapy with a firstgeneration anti-psychotic medication (Chlorpromazine) and a second generation anti-psychotic medication (Risperidone) and by their combination, both of which are commonly used in clinical psychiatric practice.

Methods: It was randomized, double-blind, controlled clinical study performed in Indian newly diagnosed schizophrenic patients in the Department of psychiatry from Feb 2003 to March 2004. Patients 18 (eighteen) patients aged 20 to 60 years diagnosed schizophrenics according to ICD-10 Criteria who visited in outpatient department of psychiatry during study period. Three groups of 6 Patient each, group-1 - was treated with oral Chlorpromazine $100 \mathrm{mg} 12 \mathrm{hly}$, group -2 - was treated with oral Risperidone $2 \mathrm{mg} 12$ hly group 3 -was treated with combination of oral Chlorpromazine 100mg 12 hly + oral Risperidone $2 \mathrm{mg} 12 \mathrm{hly}$. How symptomatology in schizophrenic patients affected, is measured by applying various validated psychiatric scales like Brief psychiatric Rating Score (BPRS), Scale for assessment of positive symptom(SAPS), and Scale for Assessment of Negative Symptoms (SANS).

Results: the study showed that the combination therapy of oral Chlorpromazine $100 \mathrm{mg} 12 \mathrm{hly}+$ Risperidone $2 \mathrm{mg} 12 \mathrm{hly}$ had reduced the overall beneficial effects which were achieved with monotherapy of both the drugs.

Conclusions: In this study, the therapeutic effects of combination of oral Chlorpromazine $100 \mathrm{mg} 12 \mathrm{hly}+$ Risperidone $2 \mathrm{mg} 12$ hly found to be reduced on positive symptoms and negative symptoms of schizophrenia, assessed on SAPS and SANS scoring scales when compared with beneficial effects which were achieved with monotherapy of both the drugs.
\end{abstract}

Keywords: Chlorpromazine and risperidone, Schizophrenia, Testosterone

\section{INTRODUCTION}

Psychosis is a symptom of mental illnesses characterized by a distorted or nonexistent sense of reality. Psychotic disorders have different etiologies, each of which demands a unique treatment approach. Schizophrenia is generally a chronic disorder that during active phase presents with delusions, hallucination, disorganized speech and disorganized behavior (known as positive symptoms) or negative symptoms such as flat affect (reduction in the range and intensity of emotional expression), Avolition (reduction, difficulty, or inability to initiate and persist in goal-directed behavior) and Alogia (poverty of speech). ${ }^{1}$ The diagnosis is made schizophrenia when these symptoms of active disease present for more than 1 month. ${ }^{2}$ The current Pathophysiology of schizophrenia that is also utilized in clinical practice is that there is excessive dopaminergic neurotransmission in the associative striatum that leads to the positive symptoms of psychosis. Blockade of dopamine receptors of D2 type (60 to $75 \%$ ) controls positive symptoms of schizophrenia as done by $1^{\text {st }}$ and $2^{\text {nd }}$ generation anti-psychotic agents. It is also found that dopaminergic hypoactivity in mesocortical area produces negative symptoms of schizophrenia (first 
generation agents produce anhedonia (inability to feel pleasure, a negative symptom, most probably due to D2 receptor blockade). ${ }^{3}$ Antagonism of 5-HT2a receptor by $2^{\text {nd }}$ generation agents (e.g. clozapine) in Meso-cortical (pre-frontal) area is important in reducing negative symptoms. ${ }^{4}$ Low-potency $1^{\text {st }}$ generation agents such as chlorpromazine are not commonly used due to the high affinities for $\mathrm{H} 1, \mathrm{M} 1$, and $\alpha 1$ receptors that result in undesirable effects (sedation, anticholinergic properties, and orthostasis). Concerns regarding QTc prolongation further limit their clinical usefulness. The $1^{\text {st }}$ generation low potency agents are useful as they are less likely to produce EPS side effects as they usually not produce excessive D2 blockade in low doses (e.g. 100mg $12 \mathrm{hly}$ ). Risperidone, a commonly used drug in clinical psychiatric practice, a $2^{\text {nd }}$ generation anti-psychotic drug that potently antagonize the 5HT2A receptor while possessing less affinity for D2 receptors than $1^{\text {st }}$ generation typical antipsychotic agents, resulting in antipsychotic efficacy with lower potential for extrapyramidal side effects. ${ }^{5}$ In clinical practice both these drugs are used from long time in varying dosage as monotherapy. ${ }^{6}$ In the recent years there has been an increase in the use of antipsychotic polypharmacy, although there are a variety of factors but poor response to monotherapy is the main cause but unfortunately there is no high quality evidence supporting antipsychotic polypharmacy for treatment resistant patients. $^{7}$ This study probes weather in some cases of schizophrenia if monotherapy either with $1^{\text {st }}$ or $2^{\text {nd }}$ generation agents not shows good therapeutic effect than in such cases the use of anti-psychotic combination therapy proved to beneficial for the patient or not i.e. weather non-evidence based use of antipsychotic polypharmacy in psychiatric clinical practice is supported by planned RCTs (evidence based medicine).

\section{METHODS}

Patients diagnosed as schizophrenic with no associated mental or medical disease and who fall into all exclusion and inclusion criteria for the clinical interaction study.

Semi structured proforma of patient consisting of:

- $\quad$ Biodata of patient

- History of illness

- Mental status and sex status

- General and physical examination notes

- Follow-up scales

- $\quad$ Adverse effect profile

Parameters/scales of diagnosis and grading the psychosis 4 types - as under (Source: Lyerly SB: Handbook of Psychiatric Rating Scale, Ed. 2, National Institute of Mental Health, Bethesda, 1973)

- $\quad$ BPRS (Brief Psychiatric Rating Scale) - 1

- $\quad$ SAPS (Scale of Assessment of Positive Symptoms) 2
- $\quad$ SANS (Scale of Assessment of Negative Symptoms) $-3$

- ICD-10 Classification for Diagnosis of Schizophrenia- 4 (Source: WHO: The ICD-10 classification of mental and behavioral disorders: Clinical Descriptions and Diagnostic Guidelines, WHO, Geneva, 1992)

Drugs and their dosage form. It includes:

- Tablet Chlorpromazine 100mg - Sun pharmaceuticals, Ahmedabad

- Tablet Risperidone (SIZODON) 2mg - Sun Pharmaceuticals, Ahmedabad

Sphygmomanometer (Diamond), stethoscope (Littman), weighing machine.

Patient signed informed consent form.

\section{Method of human exploratory clinical trial}

Objective was to study the change in therapeutic effectiveness of chlorpromazine monotherapy, Risperidone monotherapy in schizophrenic patients when given in combination in newly diagnosed schizophrenic patients.

It was randomized, double-blinded, and controlled (conventional treatment only). The study was conducted on 18 schizophrenic patients.

The study was conducted in collaboration with department of psychiatry, division of internal medicine, M.Y. Hospital, Indore and Department of Pharmacology, M.G.M. Medical College, Indore between Feb 2003 to March 2004 and followed the Good Clinical Practice guidelines (ICH).

\section{Grouping of sample population}

It depends upon therapeutic intervention. Groups are described in Table 1.

Table 1: Grouping of therapeutic interventions.

\begin{tabular}{|lcl|}
\hline $\begin{array}{l}\text { Study } \\
\text { group }\end{array}$ & $\mathbf{n}$ & $\begin{array}{l}\text { Treatment given (route, drug, } \\
\text { formulation, dose, frequency and } \\
\text { duration) }\end{array}$ \\
\hline A & 6 & $\begin{array}{l}\text { Oral tab. CPZ } 100 \mathrm{mg} \text { Twice a dayx } 28 \\
\text { days. }\end{array}$ \\
\hline B & 6 & $\begin{array}{l}\text { Oral tab. Risperidone } 2 \mathrm{mg} \text { twice a } \\
\text { dayx } 28 \text { days. }\end{array}$ \\
\hline c & $6 \begin{array}{l}\text { Oral tab. CPZ 100mg Twice a day + } \\
\text { oral tab. Risperidone 2mg twice a day x } \\
28 \text { days. }\end{array}$ \\
\hline
\end{tabular}

CPZ - Chlorpromazine, RIS - Risperidone, $\mathrm{n}=$ no. of patients in study arm 


\section{Follow up}

The follow up of patients was done in the OPD on regular/periodic basis (every $7^{\text {th }}$ day from start of study). Those cases who failed to come at the trial center were given follow-up at their homes.

\section{Design of study}

This trial was conducted in collaboration with department of psychiatry, in M.Y.H Hospital, Indore. The cases of schizophrenia are selected according to "selection criteria" which is mentioned below:

\section{Inclusion criteria}

Age-20 to 60 years schizophrenic patients diagnosed by ICD-10 Diagnostic Criteria

\section{Exclusion criteria}

- Patients who have any other physical or mental illness than schizophrenia,

- Pregnant or nursing women

- Decreased hepatic or renal function.

\section{Conduct of trial}

The antipsychotic medications used in this study is chlorpromazine and Risperidone, the dose decided for Chlorpromazine was 100mg twice daily and for Risperidone $2 \mathrm{mg}$ twice daily. The total duration of study was 28 days. The protocol and informed consent were approved by the regional ethics committee. Written informed consent was obtained for all patients. Patients are randomized according to Random Table and given Treatment by an independent contributor who did not know the nature and protocol of study to ensure proper double blinding.

As per the design of study stipulated fixed dose of antipsychotic medication were given orally for 28 days uninterruptedly in the OPD of psychiatry. The patients were instructed to come at OPD every $7^{\text {th }}$ day along with relatives for interrogations regarding medications and symptomatology of illness during the follow-up phase of the study.

The duration of follow-up was done every $7^{\text {th }}$ day till the end of study (i.e. 28 days).

The diagnosis of schizophrenia is made by ICD-10 classification, while the alteration in signs and symptoms of the illness following medication was monitored weekly by BPRS, SAPS, and SANS psychiatric rating scales., During follow-up along with the assessment of psychiatric symptoms, adverse reactions of administered drugs are also watched and along with that patients certain physiological parameter like blood pressure, pulse and weight are also monitored.

These follow-up scales and criteria of ICD-10 are satisfied by conducting interview with patient and their relatives. Each symptom and its severity are assessed by putting some questions in front of patient and members of his/her family. The presence of psychiatrist facilitates diagnosis and assessment of severity of illness.

\section{Outcome and statistical analysis}

Primary efficacy outcome measure was reduction of score of different psychiatric scoring scales BPRS (Brief Psychiatric Rating Scale), SAPS (Scale for assessment of positive symptoms, and SANS (Scale for Assessment of Negative Symptoms Paired ' $t$ ' test is used for determining level of significance ( $\mathrm{p}$ value) of intervention.

\section{RESULTS}

It is evident from the table that CPZ 200mg/day/OS for 3 weeks caused reduction in psychiatric symptoms by $24 \%$ to $28 \%$ in different psychiatric scales (Table 2).

Table 2: Effect of chlorpromazine $200 \mathrm{mg}$ orally per day on four different psychiatric scoring scales in schizophrenic patients.

\begin{tabular}{|c|c|c|c|c|c|c|}
\hline \multirow[b]{2}{*}{ Patient no. } & \multicolumn{2}{|l|}{ BPRS } & \multicolumn{2}{|l|}{ SAPS } & \multicolumn{2}{|l|}{ SANS } \\
\hline & $\begin{array}{l}\text { Pre- } \\
\text { treatment } \\
\text { score }\end{array}$ & $\begin{array}{l}3^{\text {rd }} \text { week post } \\
\text { CPZ treatment } \\
\text { score }\end{array}$ & $\begin{array}{l}\text { Pre- } \\
\text { treatment } \\
\text { score }\end{array}$ & $\begin{array}{l}3^{\text {rd }} \text { week post } \\
\text { CPZ treatment } \\
\text { score }\end{array}$ & $\begin{array}{l}\text { Pre- } \\
\text { treatment } \\
\text { score }\end{array}$ & $\begin{array}{l}3^{\text {rd }} \text { week post } \\
\text { CPZ treatment } \\
\text { score }\end{array}$ \\
\hline 1 & 57 & 43 & 111 & 88 & 59 & 43 \\
\hline 2 & 82 & 56 & 141 & 106 & 114 & 87 \\
\hline 3 & 72 & 56 & 103 & 75 & 115 & 86 \\
\hline 4 & 66 & 56 & 138 & 110 & 35 & 25 \\
\hline 5 & 70 & 61 & 143 & 111 & 104 & 79 \\
\hline 6 & 55 & 31 & 61 & 39 & 104 & 75 \\
\hline Total & 402 & 303 & 697 & 529 & 531 & 395 \\
\hline$\%$ red. in score & $24.62 \%$ & & $24.00 \%$ & & $25.61 \%$ & \\
\hline
\end{tabular}


Table 3: Effect of risperidone $4 \mathrm{mg}$ orally per day on four different psychiatric scoring scales in schizophrenic patients.

\begin{tabular}{|c|c|c|c|c|c|c|}
\hline \multirow[b]{2}{*}{ Patient no. } & \multicolumn{2}{|l|}{ BPRS } & \multicolumn{2}{|l|}{ SAPS } & \multicolumn{2}{|l|}{ SANS } \\
\hline & $\begin{array}{l}\text { Pre- } \\
\text { treatment } \\
\text { score }\end{array}$ & $\begin{array}{l}3^{\text {rd }} \text { week post } \\
\text { RIS treatment } \\
\text { score }\end{array}$ & $\begin{array}{l}\text { Pre- } \\
\text { treatment } \\
\text { score }\end{array}$ & $\begin{array}{l}3^{\text {rd }} \text { week post } \\
\text { RIS treatment } \\
\text { score }\end{array}$ & $\begin{array}{l}\text { Pre- } \\
\text { treatment } \\
\text { score }\end{array}$ & $\begin{array}{l}3^{\text {rd }} \text { week post } \\
\text { RIS treatment } \\
\text { score }\end{array}$ \\
\hline 1 & 73 & 59 & 126 & 104 & 111 & 81 \\
\hline 2 & 64 & 54 & 89 & 62 & 109 & 76 \\
\hline 3 & 52 & 43 & 121 & 70 & 63 & 47 \\
\hline 4 & 52 & 39 & 100 & 75 & 56 & 34 \\
\hline 5 & 66 & 40 & 100 & 54 & 103 & 73 \\
\hline 6 & 54 & 29 & 120 & 84 & 48 & 39 \\
\hline Total & 361 & 264 & 656 & 449 & 490 & 350 \\
\hline$\%$ red. in score & $26.86 \%$ & & $31.59 \%$ & & $28.57 \%$ & \\
\hline
\end{tabular}

Table 4: Effect of chlorpromazine $100 \mathrm{mg}$ orally per day and risperidone $2 \mathrm{mg}$ orally per day on four different psychiatric scoring scales in schizophrenic patients.

\begin{tabular}{|c|c|c|c|c|c|c|}
\hline \multirow[b]{2}{*}{ Patient no. } & \multicolumn{2}{|l|}{ BPRS } & \multicolumn{2}{|l|}{ SAPS } & \multicolumn{2}{|l|}{ SANS } \\
\hline & $\begin{array}{l}\text { Pre- } \\
\text { treatment } \\
\text { score }\end{array}$ & $\begin{array}{l}3^{\text {rd }} \text { week post } \\
\text { CPZ + RIS } \\
\text { treatment score }\end{array}$ & $\begin{array}{l}\text { Pre- } \\
\text { treatment } \\
\text { score }\end{array}$ & $\begin{array}{l}3^{\text {rd }} \text { week post } \\
\text { CPZ + RIS } \\
\text { treatment score }\end{array}$ & $\begin{array}{l}\text { Pre- } \\
\text { treatment } \\
\text { score }\end{array}$ & $\begin{array}{l}3^{\text {rd }} \text { week post } \\
\text { CPZ + RIS } \\
\text { treatment score }\end{array}$ \\
\hline 1 & 65 & 45 & 99 & 60 & 113 & 74 \\
\hline 2 & 57 & 42 & 119 & 96 & 69 & 60 \\
\hline 3 & 82 & 67 & 143 & 126 & 104 & 74 \\
\hline 4 & 70 & 60 & 124 & 113 & 43 & 39 \\
\hline 5 & 53 & 43 & 108 & 76 & 67 & 61 \\
\hline 6 & 66 & 52 & 100 & 86 & 103 & 89 \\
\hline Total & 393 & 309 & 693 & 557 & 499 & 397 \\
\hline$\%$ red. in score & $21.37 \%$ & & $19.62 \%$ & & $20.44 \%$ & \\
\hline
\end{tabular}

Table 5: Effect of oral chlorpromazine 200mg/day $12 \mathrm{hly}$ for 3 weeks in schizophrenic patients.

\begin{tabular}{|c|c|c|c|c|c|c|c|c|c|}
\hline \multirow[b]{2}{*}{$\begin{array}{l}\text { Treatment } \\
\text { Group-A }\end{array}$} & \multicolumn{3}{|c|}{ \% Reduction in BPRS Score } & \multicolumn{3}{|c|}{$\%$ Reduction in SAPS Score } & \multicolumn{3}{|c|}{ \% Reduction in SANS Score } \\
\hline & $\begin{array}{l}\% \\
\text { reduction }\end{array}$ & $\begin{array}{l}\text { 't' } \\
\text { value }\end{array}$ & $\begin{array}{l}\text { P value (level } \\
\text { of } \\
\text { significance) }\end{array}$ & $\begin{array}{l}\% \\
\text { reduction }\end{array}$ & $\begin{array}{l}\text { 't } t \text { ' } \\
\text { value }\end{array}$ & $\begin{array}{l}\text { P value } \\
\text { (level of } \\
\text { significance) }\end{array}$ & $\begin{array}{l}\% \\
\text { reduction }\end{array}$ & $\begin{array}{l}\text { 't' } \\
\text { value }\end{array}$ & $\begin{array}{l}\text { P value } \\
\text { (level of } \\
\text { significance) }\end{array}$ \\
\hline $\begin{array}{l}\text { CPZ } 200 \\
\text { mg only } \\
(\text { Control })\end{array}$ & $24.68 \%$ & 3.96 & $<0.02$ & $24 \%$ & 27.47 & $<0.001$ & $25.6 \%$ & 7.165 & $<0.001$ \\
\hline
\end{tabular}

$\mathrm{p}$ and $\mathrm{t}$-value

It is evident from the table that Risperidone $4 \mathrm{mg}$ orally per day for 3 weeks caused reduction in psychiatric symptoms by $26 \%$ to $33 \%$ in different psychiatric scales (Table 3 ).

It is evident from the table that Risperidone $2 \mathrm{mg}$ and Chlorpromazine $100 \mathrm{mg}$ orally per day for 3 weeks caused reduction in psychiatric symptoms by $19 \%$ to $22 \%$ in different psychiatric scales (Table 4).

It is evident from the table CPZ 200 12hly produce improvement in both negative and positive symptoms of schizophrenia as evident from \% reduction in SAPS and SANS score and reduction level in negative symptomology is more $(25.6 \%)$ is more as compared to positive symptomology is more (24\%) (Table 5).

It is evident from the table that Risperidone $2 \mathrm{mg} 12 \mathrm{hly}$ produce improvement in both negative and positive symptoms of schizophrenia as evident from $\%$ reduction in SAPS and SANS score and reduction level in positive symptomology $(31.59 \%)$ is more as compared to negative symptomology (28.57) (Table 6).

It is evident from the table that Risperidone $2 \mathrm{mg}+\mathrm{CPZ}$ $100 \mathrm{mg}$ daily 12 hly for 3 weeks 12 hly produce improvement in both negative and positive symptoms of 
schizophrenia as evident from $\%$ reduction in SAPS and SANS score and reduction level in positive symptomology
$(21 \%)$ is more as compared to negative symptomology $(20.44 \%)$ (Table 7).

Table 6: Effect of oral risperidone $2 \mathrm{mg} /$ day 12 hly for 3 weeks in schizophrenic patients.

\begin{tabular}{|llllllllll|}
\hline & \multicolumn{3}{c}{$\%$ Reduction in BPRS Score } & $\%$ Reduction in SAPS Score & \multicolumn{3}{c|}{ Reduction in SANS Score } \\
$\begin{array}{l}\text { Treatment } \\
\text { Group- C }\end{array}$ & $\begin{array}{l}\% \\
\text { reduction }\end{array}$ & $\begin{array}{l}\text { 't' } \\
\text { value }\end{array}$ & $\begin{array}{l}\text { P value } \\
\text { (level of } \\
\text { significance) }\end{array}$ & $\begin{array}{l}\% \\
\text { reduction }\end{array}$ & $\begin{array}{l}\text { 't' } \\
\text { value }\end{array}$ & $\begin{array}{l}\text { P value } \\
\text { (level of } \\
\text { significance) }\end{array}$ & $\begin{array}{l}\text { \% } \\
\text { reduction }\end{array}$ & $\begin{array}{l}\text { 't' } \\
\text { value }\end{array}$ & $\begin{array}{l}\text { P value } \\
\text { (level of } \\
\text { significance) }\end{array}$ \\
\hline $\begin{array}{l}\text { Risperidone } \\
\text { 4mg only } \\
\text { (Control) }\end{array}$ & $26.86 \%$ & 5.69 & $<0.01$ & $31.59 \%$ & 7.187 & $<0.001$ & $28.57 \%$ & 5.85 & $<0.01$ \\
\hline
\end{tabular}

$\mathrm{p}$ and $\mathrm{t}-\mathrm{value}$

Table 7: Effects of oral risperidone $2 \mathrm{mg}+$ CPZ 100mg daily 12 hly for 3 weeks.

\begin{tabular}{|c|c|c|c|c|c|c|c|c|c|}
\hline \multirow[b]{2}{*}{$\begin{array}{l}\text { Treatment } \\
\text { Group- E }\end{array}$} & \multicolumn{3}{|c|}{ \% Reduction in BPRS Score } & \multicolumn{3}{|c|}{$\%$ Reduction in SAPS Score } & \multicolumn{3}{|c|}{$\%$ Reduction in SANS Score } \\
\hline & $\begin{array}{l}\% \\
\text { reduction }\end{array}$ & $\begin{array}{l}\text { 't' } \\
\text { value }\end{array}$ & $\begin{array}{l}\text { P value } \\
\text { (level of } \\
\text { significance) }\end{array}$ & $\begin{array}{l}\% \\
\text { reduction }\end{array}$ & $\begin{array}{l}\text { 't' } \\
\text { value }\end{array}$ & $\begin{array}{l}\text { P value } \\
\text { (level of } \\
\text { significance) }\end{array}$ & $\begin{array}{l}\% \\
\text { reduction }\end{array}$ & $\begin{array}{l}\text { 't' } \\
\text { value }\end{array}$ & $\begin{array}{l}\text { P value } \\
\text { (level of } \\
\text { significance) }\end{array}$ \\
\hline $\begin{array}{l}\text { Risperidone } \\
2 \mathrm{mg}+\mathrm{CPZ} \\
100 \quad \text { only } \\
(\text { Control) }\end{array}$ & $21.37 \%$ & 9.15 & $<0.001$ & $21 \%$ & 5.34 & $<0.01$ & 20.44 & 3.11 & $<0.05$ \\
\hline
\end{tabular}
$\mathrm{p}$ and $\mathrm{t}$-value

Table 8: Effect of CPZ, risperidone and their combination in schizophrenic patients on BPRS, SAPS, and SANS.

\begin{tabular}{|c|c|c|c|c|c|c|c|c|c|c|}
\hline \multirow[b]{2}{*}{$\begin{array}{l}\text { Treatment } \\
\text { group }\end{array}$} & \multirow[b]{2}{*}{$\mathbf{N}$} & \multicolumn{3}{|c|}{$\begin{array}{l}\text { BPRS (Total of Group) Max. } \\
\text { Score }=648\end{array}$} & \multicolumn{3}{|c|}{$\begin{array}{l}\text { SAPS (Total of Group) Max. Score } \\
=1050\end{array}$} & \multicolumn{3}{|c|}{$\begin{array}{l}\text { SANS (Total of Group) Max. } \\
\text { Score }=720\end{array}$} \\
\hline & & $\begin{array}{l}\text { Pre- } \\
\text { treat- } \\
\text { ment } \\
\text { score } \\
\text { (Group } \\
\text { Total) }\end{array}$ & $\begin{array}{l}3 \text { weeks } \\
\text { post- } \\
\text { treat- } \\
\text { ment } \\
\text { score } \\
\text { (Group } \\
\text { Total) }\end{array}$ & $\begin{array}{l}\% \\
\text { reduction } \\
\text { in score }\end{array}$ & $\begin{array}{l}\text { Pre- } \\
\text { treatment } \\
\text { score } \\
\text { (Group } \\
\text { Total) }\end{array}$ & $\begin{array}{l}3 \text { weeks } \\
\text { post- } \\
\text { treatment } \\
\text { score } \\
\text { (Group } \\
\text { Total) }\end{array}$ & $\begin{array}{l}\% \\
\text { reduction } \\
\text { in score }\end{array}$ & $\begin{array}{l}\text { Pre- } \\
\text { treat- } \\
\text { ment } \\
\text { score } \\
\text { (Grou } \\
\text { p total) }\end{array}$ & $\begin{array}{l}3 \text { weeks } \\
\text { post- } \\
\text { treat- } \\
\text { ment } \\
\text { score } \\
\text { (Group } \\
\text { total) }\end{array}$ & $\begin{array}{l}\% \\
\text { reduction } \\
\text { in score }\end{array}$ \\
\hline $\begin{array}{l}\text { CPZ 200mg } \\
\text { only }\end{array}$ & $\begin{array}{l}6 \\
(3-M) \\
(3-F) \\
\end{array}$ & 402 & 303 & $24.68 \%$ & 697 & 529 & $24 \%$ & 531 & 395 & $25.6 \%$ \\
\hline $\begin{array}{l}\text { Risperidone } \\
4 \mathrm{mg} \text { only }\end{array}$ & $\begin{array}{l}6 \\
(3-M) \\
(3-F)\end{array}$ & 361 & 264 & $26.86 \%$ & 656 & 449 & $31.59 \%$ & 490 & 350 & $28.57 \%$ \\
\hline $\begin{array}{l}\text { CPZ 100mg } \\
+ \text { Ris. } 2 \mathrm{mg} \\
\text { only }\end{array}$ & $\begin{array}{l}6 \\
(3-M) \\
(3-F) \\
\end{array}$ & 393 & 309 & $21.37 \%$ & 693 & 547 & $21.06 \%$ & 499 & 397 & $20.44 \%$ \\
\hline
\end{tabular}

BPRS - Brief Psychiatry Rating Scale, SAP - Scale for Assessment of Positive Symptoms, SANS - Scale for Assessment of Negative Symptoms, Red. - Reduction, RIS - Risperidone, CPZ - Chlorpromazine

It is evident from the table that $\mathrm{CPZ}$ and Risperidone both reduce the psychiatric manifestations in Schizophrenia and the combination proved to be less effective in reducing effects of both positive and negative symptoms as compared to monotherapy with CPZ and RIS (Table 8).

$\%$ red. in score $=\frac{\text { Post treatment Score }- \text { Pre treatment Score }}{\text { Pretreatment Score }} \times 100$

Of the 18 patients randomized, there were no dropouts, all patients complied with treatment. No patient had taken any other treatment than given in this trial. Statistical analysis was done for all 18 patients on primary outcome measures. Out of 18 patients included in study 9 were female and other 9 were male. Average mean age of females was 36 year and males mean age was 40 years. All patients completed the study according to protocol. Base line and after treatment score on different psychiatric scale of all treatment group was given in Table 8. No significant adverse effects were reported in any patient in any treatment group. In the study, Chlorpromazine + Risperidone treated group was compared with 
Chlorpromazine monotherapy treatment group and Risperidone monotherapy treated group. It was observed in the scale which measures overall psychiatric manifestations i.e. BPRS (Brief Psychiatric Rating Scale) that there is reduction in improvement in schizophrenic patients by chlorpromazine + Risperidone treatment as compared to monotherapy of both drugs. When CPZ group is compared with CPZ + RIS group than it is found that the reduction in improvement in negative symptomology $(25.6 \% \rightarrow 20.44 \%)$ is more as compared to reduction in improvement in positive symptomology $(24.0 \% \rightarrow$ $21.06 \%)$. On the other hand, when RIS group is compared with CPZ + RIS group than it is found that the reduction in improvement in negative symptomology $(28.57 \% \rightarrow$ $20.44 \%$ ) is less as compared to reduction in improvement in positive symptomology $(31.59 \% \rightarrow 21.37 \%)$.

\section{DISCUSSION}

All psychiatric trials always have a subjective element inherent in them. In this study every effort has been made to overcoming this shortcoming by use of standardized psychiatric scales and questionnaires, involvement of a qualified and experienced senior clinical psychiatrist and Pharmacologist of a reputed Government Medical College and for funding the trial no industries are involved and conflict of interest is kept nil. Chlorpromazine (CPZ) in $1^{\text {st }}$ generation anti-psychotic drugs and Risperidone in $2^{\text {nd }}$ generation anti-psychotic drugs remain one of the most common drugs used for people with schizophrenia worldwide as monotherapy, and a benchmark against which other treatments can be evaluated. ${ }^{10}$ The makers and marketers of antipsychotics have sponsored many comparative studies, but research has shown that the sponsor's drug is frequently found to be superior. ${ }^{7}$ Similarly as already mentioned In introduction of this study there no high quality evidence supporting antipsychotic polypharmacy. ${ }^{7}$ In psychiatric clinical practice hit and trial method is very commonly practiced, the psychiatrist uses multiple anti-psychotic drugs without any reliable data from authentic randomized clinical trial or relying of biased studies which are industry sponsored rather than studies funded by government agencies. ${ }^{7,11}$ The current RCT was designed in such a way that the effect of anti-psychotic monotherapy on symptomology of schizophrenia with representative drugs from $1^{\text {st }}$ generation and $2^{\text {nd }}$ generation anti-psychotic classes are simultaneously compared with their combination in new cases of schizophrenia (new cases were taken to avoid bias of residual effect of any drug therapy received by patient on brain neurotransmission and cellular signalling). This design of RCT simplify the comparison of data emerged from study and their direct application in to the clinical psychiatric practice. The data emerged from well-planned clinical studies proves that the therapeutic decisions which were taken by the physician (based on personal experience) for the betterment of patient health sometimes goes wrong as reflected in this clinical study which shows that combination therapy of anti-psychotics commonly used in chronic resistant cases of schizophrenia found to be inferior when compared to monotherapy alone. The small sample size, short duration of study and limited dose range used may be the limitation of this study which can be obviate with designing a large trial with multiple dose range and that can be combined with the study of cellular, molecular and other factors that runs behind the therapeutic inferiority of anti-psychotic polypharmacy when compared with monotherapy.

\section{CONCLUSION}

In this clinical study therapeutic effect on positive and negative symptom of schizophrenia by combination therapy with CPZ + RIS treatment group is compared with CPZ monotherapy treated group and RIS monotherapy treatment group and drug combination (CPZ + RIS) proved to be antagonistic which is shown as reduction in improvement in positive and negative symptom of schizophrenia when compared to their monotherapy (CPZ or RIS) alone.

\section{ACKNOWLEDGEMENTS}

Author would like to thank Dr. S.K. Tongia former professor and Head Department of Pharmacology, M.G.M.M.C and M.Y.H. Hospital, Indore and Dr. Ramgulam Rajdan, professor and head department of psychiatry, M.G.M.M.C and M.Y.H. Hospital, Indore.

The present study is the part of work of author's M.D Thesis (Pharmacology) - Pharma /thesis /M.D / M.G.M.M.C/ 2003-2004/ Study of extragenital actions and drug interactions of testosterone in animals and humans.

Funding: No funding sources

Conflict of interest: None declared

Ethical approval: The study was approved by the Institutional Ethics Committee

\section{REFERENCES}

1. American psychiatric association. Diagnostic and statistical manual of mental disorders, 4th edition.' Text revision. Washington, DC, American psychiatric association; 2000.

2. Zimmerman M, Mattia JI. Psychiatric diagnosis in clinical practice: Compr Psychiatry. 1999;40:182.

3. Kahn RS, Devis KL. New developments in dopamine and schizophrenia. In Psychopharmacology: The fourth generation of progress (ed.) F.E. Bloom and DJ Kupter. Raven Press, New York; 1995:1193-1204.

4. Fusar-Poli P, Papanastasiou E, Stahl D, Rocchetti M, Carpenter W, Shergill S, et al. Treatments of negative symptoms in schizophrenia: meta-analysis of 168 randomized placebo-controlled trials. Schizophrenia Bulletin. 2014 Dec 20;41(4):892-9.

5. Jones PB, Barnes TR, Davies L, Dunn G, Lloyd H, Hayhurst KP, et al. Randomized controlled trial of the effect on Quality of Life of second-vs first-generation antipsychotic drugs in schizophrenia: Cost Utility of 
the Latest Antipsychotic Drugs in Schizophrenia Study (CUtLASS 1). Archives of general psychiatry. 2006 Oct 1;63(10):1079-87.

6. Lieberman JA, Stroup TS, McEvoy JP, Swartz MS, Rosenheck RA, Perkins DO, et al. Effectiveness of antipsychotic drugs in patients with chronic schizophrenia. New England J of Medi. 2005 Sep 22;353(12):1209-23.

7. John MK. Schizophrenia: Pharmacological Treatment: Kaplan and Sadock's comprehensive textbook of Psychiatry. 10 ${ }^{\text {th }}$ Edition; 2017;1:1519. 1529.

8. Andreasen NC. The scale for the assessment of Negative symptoms (SANS). Iowa City, IA: University of Iowa; 1983.

9. Andreasen NC. The scale for the assessment of Positive symptoms (SAPS). Iowa City, IA: University of Iowa; 1984.
10. Leucht S, Corves C, Arbter D, Engel RR, Li C, Davis JM. Second-generation versus first-generation antipsychotic drugs for schizophrenia: a metaanalysis. Lancet. January 2009;373(9657):31-41.

11. Biancosino B, Barbui C, Marmai L, Donà S, Grassi L. Determinants of antipsychotic polypharmacy in psychiatric inpatients: a prospective study. International Clinical Psychopharmacology. 2005 Nov 1;20(6):305-9.

Cite this article as: Vijaywargia T. Comparison of therapeutic effects of monotherapy of chlorpromazine, risperidone and their combination in newly diagnosed schizophrenic patients. Int J Basic Clin Pharmacol 2018;7:1273-9. 